\title{
Control in the inter-organizational management accounting system
}

\author{
Liudmila Khoruzhiy", and Anastasiya Romanova ${ }^{1}$ \\ ${ }^{1}$ Russian State Agrarian University - Moscow Agricultural Academy named after K.A. Timiryazev, \\ Institute of Economics and Agribusiness Management, 49 Timiryazevskaya Str., 127550 Moscow, \\ Russia
}

\begin{abstract}
This article discusses the main concepts of the interorganizational cooperation model, inter-organizational accounting and analytical system and the role of control in the management accounting system of partners. The main objective of the research is to build a management accounting model of enterprises at the inter-organizational level, which operates on the basis of self-organization and takes into account different levels of interaction of the enterprise. The management accounting model focuses on the role and place of control in the complex structure of relationships between enterprises and partners in the framework of inter-organizational management accounting. The control element is an important part of building a fundamentally new interorganizational accounting and analytical system. This is due to the complexity of this structure, the presence of an unlimited number of subjects of inter-company relations and management levels. Establishing an effective control system will prevent a conflict of goals between partnership subjects, balance the interests of partners, and carry out coordinated adoption and implementation of decisions on the functioning and interaction in the network.
\end{abstract}

\section{Introduction}

The rapid change of competitive advantages of organizations in modern market conditions has led to the need to develop new ways to ensure long-term competitive advantages. Integration processes in the economy forced enterprises to interact with partners and increased the degree of dependence of organizations on each other. The effectiveness of an individual economic entity in such conditions is closely related to the level of inter-company relations. Business operations on the basis of partnership allowed us to achieve long-term competitiveness due to the synergistic effect.

Inter-organizational cooperation is a system of organizational, functional and process relationships between economic entities united by common mutually beneficial objectives that are achieved through the synergistic effect of partnership with a high level of business culture, voluntary and on trust. Among the elements of the inter-organizational level the following is highlighted: process of inter-organizational cooperation; subjects and objects

\footnotetext{
*Corresponding author: dka1955@mail.ru
} 
of inter-organizational cooperation; methods, tools, products; level of inter-organizational cooperation; ensuring cooperation [1].

Among the highlighted elements, ensuring inter-organizational activities is the broadest category. In a broad sense, it includes joint information and communication systems, information, analytical and organizational support (including rationalization of the system organization), and the process of existing system optimization (including attracting new elements, activities or functions). This element includes accounting and analytical system for inter-organization cooperation, inter-organization management accounting, and interorganization control system.

\section{Materials and Methods}

The accounting and analytical system is an integral part of inter-organizational cooperation. The accounting and analytical system is a system based on accounting information that includes statistical, technical, social, and other types of information. The accounting and analytical system is designed to provide management decisions with the necessary amount of information [2].

Management accounting plays an important role in development and stable development of financial and economic activities of economic units. Management accounting takes a central place in the accounting and analytical system, due to the change of hierarchical structures of interaction between companies to the inter-company principle of self-organization of independent companies. Partnership relations between groups of companies require improvement of mechanisms for managing organizational chains of members of inter-organizational cooperation, including the development of management accounting system at the inter-company level.

Management accounting, according to L.I. Khoruzhiy, is "an accounting and management system consisting in subject-object management relations based on registration of economic activity facts, obtaining management information and allowing to provide a choice of alternative management decisions" [3].

The system of management accounting within the chain of partner firms has a fundamentally new character of setting and functioning. Inter-organizational management accounting is a type of activity within the framework of inter-organizational cooperation that provides interaction subjects with information used for planning, analyzing, managing and monitoring the activities of cooperation as a whole and an individual economic entity in order to grow, develop, and maintain the economic security of the inter-organizational cooperation system. The fundamental difference of accounting is that at the level of intercompany cooperation, there is a need to overcome the shortcomings of market, administrative, and legal mechanisms for conducting business, and to build a strict system of control over decision-making while maintaining cooperation on the principles of voluntariness and self-organization of partners. Changing the usual hierarchical structure of managing activities and processes of cooperation and its individual members to a decentralized management system requires setting up a qualitatively new control system. Currently, the most relevant issue is to consider control as an element of a complex system of interaction between partners, as well as the formation of the control system structure.

It is advisable to consider the problem of cooperation control in the context of management accounting in order to clearly trace the role, functions, and fundamental differences of the control system in the network of relationships within the system of interorganizational management accounting. The nature of relationships in the system of interorganizational cooperation, on the one hand, can be described as complex systems that evolve according to the principle of synergy. Subjects seek to cooperate to achieve common interests, forming adaptable and changeable chains of relationships. The effectiveness of 
such chains of relationships and their transformation into a system of inter-organizational relations requires the development of functioning basics, from subjects, monitoring of their activity to integrating mechanisms, on the other hand.

The control system within the framework of inter-organizational cooperation is a communication network of inter-organizational management accounting, which ensures the implementation of management decisions in practice and lays down ways to develop cooperation. Control consists of methods, tools and mechanisms for influencing the subjects and objects of inter-organizational cooperation in responsibility centers [4,5]. The relationship between the structure of inter-organizational control and the organizational structure of cooperation allows to build a schematic diagram of the control system (Fig. 1).

\begin{tabular}{|c|c|c|}
\hline Partner A & Partner B & Partner C \\
\hline & $\begin{array}{l}\text { - financial accounting; } \\
\text { - management accounting; } \\
\text { - tax accounting; } \\
\text { - internal control system. }\end{array}$ & \\
\hline \multicolumn{3}{|c|}{ Primary level of inter-organizational cooperation } \\
\hline $\begin{array}{c}\uparrow \\
\text { verification of information } \\
\text { receipt }\end{array}$ & $\begin{array}{l}\uparrow \\
\downarrow \\
\text { verification of information } \\
\text { relevance and reliability }\end{array}$ & $\begin{array}{c}\uparrow \\
\text { reflection of control measures } \\
\text { results }\end{array}$ \\
\hline \multicolumn{3}{|c|}{ Secondary level of inter-organizational cooperation } \\
\hline Tax analysis & Financial analysis & Management analysis \\
\hline \multicolumn{3}{|c|}{ Inter-organizational control system } \\
\hline$\downarrow$ & $\downarrow$ & $\downarrow$ \\
\hline Management accounts & $\begin{array}{c}\text { Management control indicator } \\
\text { system }\end{array}$ & $\begin{array}{l}\text { Improvement based on the } \\
\text { results of control measures }\end{array}$ \\
\hline
\end{tabular}

Fig. 1. Place of control in the inter-organizational accounting and analytical system.

Figure 1 shows the schematic diagram of the inter-organizational accounting and analytical system and the place of the control system at the inter-company (secondary) level and at the primary level (company level).

The transition of information flows from the primary to the secondary level is represented by direct and inverse relationships. In the process of information exchange, the main control points are highlighted: verification of information receipt; verification of information relevance and reliability and reflecting the results of control measures (feedback).

The secondary level is represented by tax, financial and management types of analysis and a system of inter-organizational control. All the selected subsystems function interconnected with each other, which is represented in the diagram as circles intersections. The effective control system analyzes not only retrospective data, but also forecasts for the future, as well as the subjects of control actively carry out current control measures continuously. The result of control activities of subjects at the inter-organizational level is the preparation of management reports, evaluation of the system of indicators and development of measures to improve cooperation based on the results of control activities. 


\section{Results and discussions}

The relationship between the inter-company control system and the inter-organization management accounting system is that control is a broad and multidimensional concept. Control measures of complex inter-organizational structures should cover all the specifics of such integration associations. Therefore, the development of measures, tools, means and control mechanisms is carried out in the following aspects: by partners (by subjects); by functional characteristics (in detail by type of activity); by individual business processes; by responsibility centers and by management accounting objects (Table 1) [6,7].

Table 1. Classification of control by attributes on the example of three partners.

\begin{tabular}{|c|c|c|c|}
\hline Classification feature & Partner A & Partner B & Partner C \\
\hline $\begin{array}{l}\text { In the context of } \\
\text { partners }\end{array}$ & Partner 1 & Partner 2 & Partner 3 \\
\hline \multirow[b]{2}{*}{$\begin{array}{l}\text { Control by type of } \\
\text { activity }\end{array}$} & Production & Processing & Distribution \\
\hline & $\begin{array}{l}\text { Production of crop, } \\
\text { animal husbandry and } \\
\text { other products. }\end{array}$ & $\begin{array}{c}\text { Processing of crop, } \\
\text { animal husbandry, } \\
\text { other products. }\end{array}$ & $\begin{array}{l}\text { Distribution of crop } \\
\text { animal husbandry } \\
\text { and } \\
\text { other products. }\end{array}$ \\
\hline $\begin{array}{l}\text { Business process } \\
\text { control }\end{array}$ & \multicolumn{3}{|c|}{$\begin{array}{l}\text { According to the selected business processes of each partner (primary } \\
\text { level) and secondary level (cooperation level) }\end{array}$} \\
\hline $\begin{array}{l}\text { Control by } \\
\text { responsibility centers }\end{array}$ & \multicolumn{3}{|c|}{$\begin{array}{l}\text { According to the selected division of each partner (team, shop, } \\
\text { department, site). }\end{array}$} \\
\hline $\begin{array}{l}\text { Control in the context } \\
\text { of accounting objects }\end{array}$ & \multicolumn{3}{|c|}{ According to the developed unified management accounting accounts } \\
\hline
\end{tabular}

When developing mechanisms and tools for an inter-company control system taking into account the classification presented in table 2 the main requirements for building control activities of an inter-organizational structure will be met: cross-functional, intercompany and intra-company features of cooperation and its members are taken into account.

According to the algorithm for setting up the management accounting system at the inter-organizational level, control measures for testing the management accounting system in the context of code groups for the cooperation management accounting account are identified as a separate stage [8]. Comparative tables as a tool for control activities when setting up management accounting will allow to identify problem areas and eliminate them at the stage of test launch of the accounting system [9].

The management accounting account at the inter-organizational level is represented by twelve characters in the form of five groups of codes [10]. Let's present the relationship of control in the inter-organizational management accounting system through the management accounting account (Fig. 2).
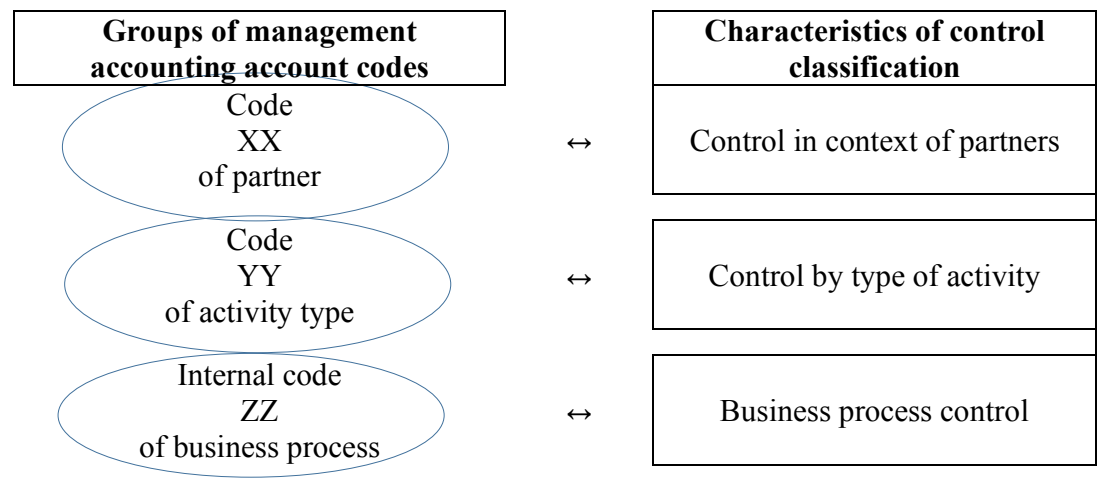


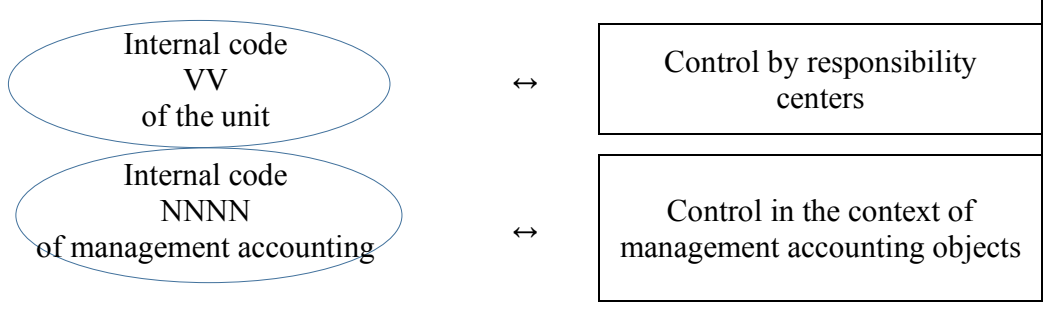

Fig. 1. The relationship between management accounting and control at the inter-organizational level.

The figure shows a model of control integration and management accounting. At the inter-organizational level, analysis, control, and accounting function in a close relationship, which affects their functions.

The accounting system performs the following functions: collection of information and elimination of defects in it; generalization and systematization of information; reporting. Functions of the control system: collection of specialized information and its reflection in specialized reports; conducting comparison procedures; development of improvement tools and integration of control results. The analysis system performs the following functions: determines indicators of the state of cooperation; identifies the causes and conditions of the state of cooperation; defines a typical management situation and establishes patterns of changes in the situation. The information flow from the primary level passes to the intercompany level and goes through the analysis, accounting, control procedures; reports are generated at the output, questions are formulated about the admissibility and inadmissibility of identified deviations and their causes, the enterprise model and management decision stereotypes are built $[11,12]$.

\section{Conclusions}

1. inter-organizational cooperation is the key to ensure the economic security of individual partners and their associations. Due to the complexity of the organizational structure, it is necessary to develop fundamentally new accounting, analysis and control systems and integrate them.

2. The relationship and place of control in management accounting is expressed by detailing control and its tools in the context of groups of management accounting account codes. It is advisable to carry out control measures in the context of cooperation members, types of activities, business processes, divisions and accounting objects

\section{Acknowledgements}

The research was supported by the Russian State Agrarian University - Moscow Timiryazev Agricultural Academy, theme №1.2.12

\section{References}

1. L.I. Khoruzhiy, Yu.N. Katkov, A.A. Romanova, Accounting in Agriculture, 11, 67-77 (2019)

2. L.V. Popova, B.G. Maslov, I.A. Maslova, Financial Management, 3, 34-67 (2008)

3. L.I. Khoruzhiy, Problems of theory, methodology, methods and organization of management accounting in agriculture (Moscow: Finance and Statistics, 2004) 
4. E.Yu. Merkulova, L.G. Abdukarimova, E.A. Baeva, Accounting, (Tambov: Derzhavinsky Publishing House, 2019)

5. A.F. Myalkina, N.M. Turbina, Socio-Economic Phenomena and Processes. Tambov, 9(10), 80-86 (2014)

6. B. Andersen, Business processes. Tools for improvement (Moscow: RIA "Standards and Quality", 2003)

7. A.N. Stkrgilova, Logistics and Management of Supply Chains, 6, 70-78 (2005)

8. L.I. Khoruzhiy, Yu.N. Katkov, A.A. Romanova, Accounting in Agriculture, 6, 19-29 (2020)

9. D.D. Kostoglodov, Distribution logistics (Moscow: Expert Bureau, 1997)

10. L.I. Khoruzhy, T.N. Gupalova, Yu.N. Katkov, International Journal of Innovative Technology and Exploring Engineering (IJITEE), 8(7), 748-75 (2019)

11. L.I. Khoruzhy, V.M. Bautin, Yu.N. Katkov, E.I. Stepanenko, B.V. Lukyanov, Espacios, 39(47), 19 (2018)

12. V.V. Fetschenko, E.M. Shadoba, Yu.N. Katkow, N.Yu Shchelikova, N.V. Glushak, Procedia - Social and Behavioral Sciences, «Worldwide trends in the development of education and academic research, 214, 243-250 (2015) 